\title{
A POÉTICA DA VOZ E O VAZIO DA ESCRITA: PARTE DA EXPERIÊNCIA DE UMA PESQUISA
}

\section{THE POETICS OF THE VOICE AND THE EMPTY OF THE WRITING: PART OF THE EXPERIENCE OF A RESEARCH}

\author{
Renata Ávila Troca ${ }^{57}$
}

\begin{abstract}
RESUMO: As linhas que seguem foram recortadas de um texto maior, uma tese. Nela tentei traçar um diálogo escrito entre memórias de duas senhoras que se encontram dentro e fora de casa. Diante de inúmeros aspectos que poderia apresentar neste texto, escolhi apresentar o meu encontro com elas e o processo de escrita. O vazio que ocorre na grande maioria dos escritores foi um dos maiores companheiros desses anos de pesquisa. $\mathrm{O}$ grande potencial de material que eu tinha fazia com que eu me sentisse com nada, uma vez que me sentia incapaz de filtrar e selecionar dentre tanta riqueza que me chegava. Diana Klinger (2014) é a responsável por me respaldar teoricamente nesta ligação entre literatura e a conceituação do vazio. Seguindo, encontro com autores que defendem a Poética da Voz como elemento literário e vivo, e, portanto, somente aí apresento minhas narradoras: Idosas, negras, periféricas, com ações sociais, e por quem me afetuei.
\end{abstract}

PALAVRAS-CHAVE: Literatura. Vazio. Afeto. Poética da voz. Memória. Escuta.

ABSTRACT: The lines that follow were cut from a larger text, a thesis. In it, I tried to draw a written dialogue between memories of two ladies who are in and out of the house. Given many aspects that I could present in this text, I chose to present my meeting with them and the writing process. The emptiness that occurs most writers was one of the greatest companions of these years of research. The great potential of material I had made me feel nothing, since I felt unable to filter and select from the wealth that came to me. Diana Klinger is responsible for supporting me theoretically in this connection between literature and the conceptualization of emptiness Following, meeting with authors who defend the Poetics of the Voice as literary and living element, and therefore, only there, I present my narrators: Elderly, black, peripheral, with social actions and for whom I have been affected

KEYWORDS: Literature. Void. Affection. Poetic of the voice. Memory. Scout

A voz vem do ser.
A voz vem do sangue
A voz vem das vozes
Caídas na luta
Perdidas no cerco
Do tempo cumprido
Nas dobras do pranto
(Ruy Duarte de Carvalho)

O traçado das linhas que se segue é a apresentação de uma parte da minha tese de doutorado, defendida em 2017, pelo PPGLetras da UFRGS. Abordo aqui uma das problemáticas da escrita acadêmica, o vazio, ou ainda, a angústia de ter que preenchê-lo. A pesquisa, realizada a partir das memórias de duas senhoras, tem por objetivo ouvir a poética da voz ${ }^{58}$ que delas se extrai para tentar colocá-la no papel. Ou como diz José Batista Dal Farra Martins captar o grito, a sensação, a performance, a voz que "a despeito de sua invisibilidade, [...] se concretiza como som, palavra, ruído e silêncio, nos movimentos de pulso e tom, nos contrastes das intensidades, [...] na dança prosódica das inflexões, na diversidade de timbres engendrados pelas ressonâncias." (MARTINS, 2007, p. 9). Tentar colocar na página aquilo que não é nomeável, descritível... Ou ainda na dança das palavras de Diana Klinger atreladas às de Clarice Lispector:

\footnotetext{
${ }^{57}$ Doutora e mestre em Literatura luso-africana (UFRGS/2017). Professora de Língua portuguesa e Literatura Brasileira da Secretaria de Educação do Estado do Rio Grande do Sul (SEDUC/RS). renataa.t@hotmail.com ${ }^{58}$ A este respeito, pesquisar Paul Zumthor (1993).
} 


\begin{abstract}
Quero apossar-me do e da coisa. Esses instantes que escorrem no ar que respiro: em fogos de artifício, eles espocam mudos no espaço." "O que falo é puro presente e esse livro é uma linha reta no espaço." É sempre atual, e o fotômetro de uma máquina fotográfica se abre e imediatamente fecha, mas guardando em si o flash. Mesmo que diga "vivi" ou "viverei" é o presente porque eu os digo já."; Então escrever é o modo de quem tem a palavra como isca: a palavra pescando o que não é palavra. Quando essa não palavra - a entrelinha - morde a isca, alguma coisa se escreveu." Não pinto ideias, pinto o mais inatingível "para sempre." Ou "para nunca", é o mesmo. Antes de mais nada, pinto pintura. E antes de mais nada te escrevo uma escritura. "Não se compreende a música: ouve-se. Ouve-me então com teu corpo inteiro. (KLINGER, 2014, p. 36-37, grifos da autora).
\end{abstract}

Penso que as frustradas pescas do preenchimento da palavra de Lispector são insatisfatórias, pois as redes - as iscas de pescar a palavra - fisgam não apenas a entrelinha, mas a escuta daquilo que é gesto e silêncio querendo ser voz. A palavra é afeto. A palavra, enfim, não é somente a escrita. A palavra é dor! É isolamento ou/e também socialização. A palavra é grito e também silêncio.

A palavra é movimento e o parar. Letra e voz são armas que aprendemos a usar para fazer com que a palavra possa ser exposta a um mundo que deixe de ser só nosso, como pede a narradora de Lispector: "Ouve-me então com teu corpo inteiro". Necessitamos de ser escutados, pois há uma captura dos afetos, no que segue Klinger falando, "os afetos dizem respeito a relações e não a indivíduos." (KLINGER, 2014, p. 73). Relações essas que a palavra escrita não dá conta de saciar, causando, assim, um vazio no escritor.

\footnotetext{
$\mathrm{O}$ afeto excede o vivido, as percepções e os sentimentos. Entendem-se por afeto os efeitos corporais de uma dinâmica relacional, tanto sensoriais, conscientes ou não, como emotivos, já conscientes. Os afetos surgem nas relações, na capacidade de agir, ser atingido entre corpos. Corpos não possuem afetos, mas potencialidades de afetar, pois os afetos acontecem na relação, em função da relação. Não são propriedades de um corpo, mas eventos, marcas e vestígios de um encontro, de uma dinâmica relacional. (KLINGER, 2014, p. 81, grifo da autora).
}

Nesta perspectiva, Mia Couto, escritor moçambicano, no conto A menina sem palavras, apresenta uma relação de pai e filha em que só essa potencialidade de afetar é que faz a palavra existir e ser entendida.

A menina não palavreava. Nenhuma vogal lhe saia, seus lábios se ocupavam só em sons que não somavam dois nem quatro. Era uma língua só dela, um dialecto pessoal e intransigível? [...] Quando lembrava as palavras ela esquecia o pensamento. Quando construía o raciocínio perdia o idioma. Não é que fosse muda. Falava em língua que nem há nesta actual humanidade. [...] Seu pai muito lhe dedicava afeição e aflição. Uma noite lhe apertou as mãozinhas e implorou, certo que falava sozinho: - Fala comigo, filha! Os olhos dele deslizaram. A menina beijou a lágrima. Gostoseou aquela água salgada e disse: - Mar... (COUTO, 2013, p. 33).

Desta forma, o escritor nos apresenta o vazio da palavra que é preenchido com a troca de afetos.

Enfim, a troca de afetos proporciona que a palavra exista e ganhe sentido. E, assim, "Não (me) resta quase nada: nem a coisa, nem a sua existência, nem a minha, nem o puro objeto nem o puro sujeito, nenhum interesse de nenhuma natureza por nada." (KLINGER, 2014 , p. 30). Independente do escrito ou do oral, o afeto só poderá se manifestar preenchendo este vazio se encontrar quem com ele possa afetar e assim ser afetado. 
Klinger diz que "A literatura é meu pacto silencioso com o vazio do mundo. Não é meu consolo. É minha aceitação, meu amor fati. Meu compromisso.” (KLINGER, 2014, p. 14). Entendo que a palavra, a estética da palavra, seja ela escrita ou não, precisa ser viva.

É dessa forma que chego à apresentação da poética por mim ouvida, sentida, vivida:

\begin{abstract}
(...) a escuta dessas outras vozes em eco descentra a própria voz. Assim, essa poesia vai se inscrevendo no limiar, entre o próprio e o impróprio, o poético e o prosaico, entre o verso e a narrativa. Também entre a articulação e a desarticulação, pois o poema nunca repõe a memória nem a fala do outro, mas, pelo contrário, rodeia seus vazios. (KLINGER, 2014, p. 98).
\end{abstract}

Diferentemente da escrita, nas atuações de oralidade, o vazio pode ser suprido de imediato, ou nas palavras de Ana Lúcia Liberato Tettamanzy, "o narrador se reinventa na presença daquele que o escuta." (TETTAMANZY, 2010, p.13). Porque todo o escrito pede um leitor, assim como toda voz, um ouvinte:

Como dar conta da complexidade envolvida nas experiências de campo, em que pesquisadores, autorizados pela objetividade da tradição lógico-formal e pelo domínio da escrita, deslocam-se em direção a grupos e espaços tidos como subalternos ou periféricos para a realização de estudos? (TETTAMANZY, 2010, p. 11).

É a pergunta que me persegue desde a graduação (onde não havia espaço para a voz), crescendo na especialização (quando consegui defender meu artigo final em forma de fábula oral e produzir meu primeiro documentário ${ }^{59}$ relacionado - ainda sem saber que assim era - à poética da voz) e que amadureceu no mestrado, ao ouvir Seu Beto e "propor que narrativas orais de pessoas comuns possam constituir uma poética e merecer empreendimento analítico". (idem, p.12), tanto quanto as narrativas da escritora angolana Ana Paula Tavares.

No doutorado, Dona Sirley e Dona Enilda, quem entrevistei e de quem ouvi muitas histórias, me proporcionaram estabelecer semelhanças e diferenças ao sentir suas vozes: doces, femininas, negras e velhas. A voz, portanto, continua sendo o meu alimento de força e energia em relação aos conhecimentos que tenho adquirido com pesquisas que me aprofundam na definição mais adequada (pelo menos para mim) do que é, de fato, Literatura. No entanto, é necessário frisar, que, como bem aborda Frederico Augusto Garcia Fernandes:

Uma das principais características da literatura é que a vida e literariedade estão enleadas. Mas para que um fenômeno efetive-se como literatura é necessário o espírito soprar sob a pena ou fazer vibrar a voz. O escritor dá uma outra dimensão a tais fatos cotidianos e sentimentos, torna-os pungentes, reelabora-os, fixando-os no tempo com a palavra impressa. O contador, por sua vez, consome os momentos, cada fato vivido é uma aventura que ele pode compartilhar nas suas rodas de conversa. Ele procura encantar com a magia dos sons das palavras e divertir os ouvintes com gestos e expressões impressas em sua face. Conta o mesmo fato inúmeras vezes, fundindo lembranças alheias, trocando palavras, incorporando personagem. (FERNANDES, 2002, p. 13).

Fernandes apresenta a diferença de sensações e valores que o escritor e o contador dão à vida e à sua literariedade, porém ele frisa que a diferença está onde o "espírito sopra" ou sob a pena ou na vibração da voz. Ou seja, entendo eu, a intenção de fazer literatura é a mesma, a forma a qual ela se

59 TROCA, Renata Ávila. Manuela. O futuro de uma delicadeza. Disponível em https://www.youtube.com/watch?v=UMM5YpB1GHc. Acesso em 17 de maio de 2016. 
manifesta é que é diferente devido aos instrumentos utilizados por quem faz literatura e por quem faz performance, narra oralmente, com o corpo.

Eu sei que antes de mostrar a caça, eu deveria apresentar as caçadoras, suas biografias e como o meu traçar de caminho cruzou com o delas. Mas acontece que essa questão da oralidade é assim mesmo, as coisas se confundem e se mostram em momentos inoportunos. Então, peço aqui licença para contar a vocês essas histórias.

Puxa um banco aí para a gente ter um dedo de prosa!

\section{Elas e eu}

Dona Enilda é moradora do mesmo bairro que eu, Vila da Quinta (Rio Grande/RS) e, por meu pai ter um comércio, somos uma família conhecida na pequena comunidade. Ela é cliente dele há muitos anos, por isso me conhece desde a infância.

Certo dia, quando adolescente, eu estava ajudando a abastecer as prateleiras do mercado, e ela chegou perto de mim (nossas conversas até então eram sempre de superficial simpatia (- Oi, tudo bem? - Tchau) eu estava numa escada, ela pediu para eu descer e me disse assim: "- Olha, eu não sou de me meter na vida dos outros, mas recebi uma mensagem que preciso te passar. Esse rapaz com quem tu tá namorando não tem interesse em ti não, tu tá valorizando mais que ele merece." E, sorrindo, foi embora. Eu fiquei ali, segurando a escada, boquiaberta, porque já conhecia a benzedeira mística e silenciosa que ela era, mas nunca tinha tido um contato tão imediato quanto este. No mesmo dia, liguei para o rapaz (que era impossível de ela conhecer, pois era de uma cidade e cultura diferentes) e disse que não iria mais procurá-lo, mas que esperaria por ele quando ELE tivesse saudades. Bom, se ainda estivesse esperando, seria mais uma frustrada abandonada ao telefone.

Desde então, (isso deve ter se passado cerca de 25 anos, mais ou menos), comecei a frequentar a casa dela, pedindo conselhos e benzeduras. Sempre com carinho, atenção, amizade e certo afastamento. Talvez até por medo do enigmatismo e misticismo que ela carrega no olhar. Nunca soube direito, até agora, como me aproximar mais intimamente desta protetora espiritual que ganhei, e que sempre me protege dos perigos que prevê.

Dona Sirley cruzou a minha encruzilhada de boas vibrações no XXI Acampamento de Cultura Afro, que ocorre anualmente em São Lourenço do Sul (SLS/RS). Não foi muito difícil falar com ela, porque é uma tagarela de mão cheia e tem paixão por quem quer a ouvir. A partir daquele evento, de 2014, tive a certeza de que trabalharia com ela, em forma de pesquisa na oralidade.

Fiquei com a dona Sirley nos braços, como um tesouro que precisava proteger, mas que não via por onde seguir. Sentei-me em meio à negrura do vazio, com o brilho do cesto de adivinhações em mãos, e olhei aos céus: Não há luz/ não há estrelas no céu escuro/Tudo na terra é sombra (NETO, 1974, p. 9). Foi o que o poeta angolano Agostinho Neto me fez lembrar. Percebi então que deveria percorrer outros caminhos que não olhar o céu: as pedras do rio, aquelas por onde águas mansas correm tranquilas, junto às turbulentas que recebem a queda do que vem do desconhecido com magia e encanto. E foi assim, com a abertura do leque de Oxum, que consegui visualizar, em seu espelho, a silenciosa Dona Enilda ao lado da tagarela Dona Sirley.

Eu já tinha o aceite de dona Sirley para a pesquisa e já tinha feito várias gravações de áudio e imagem, em diferentes formas de ela contar sua história. O convite à dona Enilda veio de forma mais natural possível. Encontrei-a atravessando a rua e disse que queria ir à sua casa conversar, pois queria fazer uma pesquisa sobre sua história de vida. Ela me disse assim: “- É tão bom escutar os outros, não é? Pode ir lá, sim.” Engraçado lembrar disso com tanta riqueza de detalhes, porque hoje ela me ligou. (Com a escrita da tese, eu tenho me afastado de tudo e todos. Não a visito há alguns dias) E me disse: “ - Oi, eu liguei pra Renata pra escutar a fala 
dela." E riu. Eu não entendia bem o que ela dizia, e mais ela ria ao tentar me explicar: " - Ué, se eu te liguei é porque quero te escutar, não é?" E ria, ria muito. Agora, quem fala, sente falta de ouvir. Depois disse que tem pedido aos pais dela, dia e noite, pela minha saúde e que tudo iria acabar bem. Ligou-me para me dar um axé, já que não tenho ido lá. Sempre que vou visitá-la, ou ela me benze, ou faz alguma reza, ou me presenteia com um banho de ervas para minha proteção. Mas nunca saio de lá sem a proteção dela, seja como for. É uma sensação tão estranha, distanciar-me para poder chegar perto de minhas narradoras. "Passam por mim/e eu sigo-as através de mim [...].” (NETO, 1974, p. 3). Um afastamento que traz consigo o afeto impregnado de presença.

Sábado à noite vi algumas fotos que dona Sirley postou nas redes sociais de um evento que estava participando e enviei uma mensagem: " -Tô morrendo de saudades! Tô na correria, enlouquecida. Mês que vem estarei mais folgada e vou te procurar. Grande axé. Beijão da Renata." E ela responde quase que imediatamente: "- Abração e beijão. Bom Trabalho. Sirley." Agora relendo para explanar aqui, percebi o distanciamento emocional que a mensagem de dona Sirley pode acarretar, principalmente, depois de ter descrito a força e proteção que as conversas com dona Enilda me dão. Mas não. Sei que dona Sirley tem tanto carinho e proteção a mim quanto dona Enilda, apenas são formas diferentes de entender o meu distanciamento.

Dona Sirley também está sempre com a agenda cheia, com compromissos que ela jura que nunca mais irá assumir e que o faz na próxima oportunidade que surge. Justifica a caminhante-camarão

Tenho umas regras pra viver, mas de modo geral, a minha própria caminhada não
deixa eu ter minhas regras certas. Sobre isso e aquilo. Eu criei um ditado pra mim
que eu acho muito interessante. Eu vou muito à praia, desde muito nova, e nunca
cheguei a tá numa praia que eu visse camarão chegar, não me lembro, mas eu
costumo muito dizer que eu sou como o camarão na onda, a onda quando traz o
camarão leva ele pra tudo que é lado. Daqui a pouco pra cá, depois pra lá. Quando
vê tá na beira do mar. Não é? Então, eu sou muito camarão. Até tem um samba da
Elisete de Carvalho que diz: “ Camarão que a onda leva, lalarilalá...." Então, pra
planejar que eu vou aqui e ali, é incrível. E, às vezes, eu tô em casa, agora, um dia
desses, falando em solidão, eu tava... eu consegui ficar um pouco, eu andei saindo
um pouco, mas eu tava em casa. E meu plano era... nesses dias de carnaval, eu
consegui ficar quatro dias em casa sem sair, e eu tava em casa com planos de não
sair. Mas dai já me ligaram pra eu sair não sei pra que, e eu já sai e mudou toda a
programaçãa. E, às vezes, eu tô pronta pra sair e "olha, mudou..." Te lembra uma
vez que eu tava aqui, era algo, uma despedida, que ia ter, eu acho... não sei se de
alguma oficina que eu tinha... era a oficina de inglês. E nós ia indo ali no meio da
estrada e a professora cancelou. E ai nós damos volta, e fizemos outra programação.
Então, eu mesmo não confio muito em minhas programações, porque eu acho que
tenho sempre um secretário secreto. (risos) que faz a minha programação. Ah, eu
acho essa variação tão interessante. (Gravação pessoal Dona Sirley, 19 de fevereiro
de 2016 .)

Começo a fazer parte de um segmento na vida pessoal delas, tanto quanto elas na minha. E é nesse sentido que o afeto é o que mais enche o vazio dessa escrita. Dona Sirley, como adora passear, já veio tirar uns dias na minha casa, ano passado e este ano também. Dona Enilda, como não gosta de sair de casa e sabe que simpatizo e respeito os ritos religiosos, pede-me que troque a água das quartinhas de santo dela; que busque água de rio para os banhos que ela prepara, que despache alguma imagem ou material santo que tenha sido quebrado, por exemplo. Enfim, eu sei que ela confia a sua fé a mim porque sabe que eu respeitarei os atos que podem parecer simplistas a quem não entende, mas são importantíssimos a ela, como umbandista. 
Ao afirmar que a história de vida só pode ser uma ilustração do funcionamento de uma sociedade e, como tal, ela remete previamente para a mais rigorosa análise das estruturas, das produções materiais e mentais dessa sociedade. Eckert justamente esclarece o quanto esse método não se basta a si mesmo.

\begin{abstract}
Essa técnica é utilizada como importante fonte de pesquisa, mas sua importância maior se dá na medida da sua correlação com as demais fontes de dados do método etnográfico: a convivência prolongada que permite uma observação antropológica elaborada, o conhecimento dos ritmos e espaços da vida cotidiana, os complexos eventos coletivos, as múltiplas redes sociais onde os indivíduos circulam e negociam identidades (os rituais, os laços familiares, de parentesco, o poder social, os agentes, etc.) (ECKERT, 2006, p. 23).
\end{abstract}

Acredito que com o avanço da pesquisa e minha consequente presença em sua casa fizeram com que Dona Enilda revisse a importância de sua forma ao apresentar-se à fala. Ela sempre foi muito reservada e natural, mesmo diante da câmara de gravação. Não me esperava arrumada para as gravações. No entanto, liguei dia 02 de fevereiro, em homenagem a mãe Iemanjá e, no decorrer da conversa, ela me disse: - Ah, que bom que ligasse. Eu queria que tu viesses aqui... porque tô com umas invencionices minhas.

Seguem as invencionices maravilhosas que ela me presenteou:

\title{
1.1 A descoberta de dona Enilda, por ela mesma
}

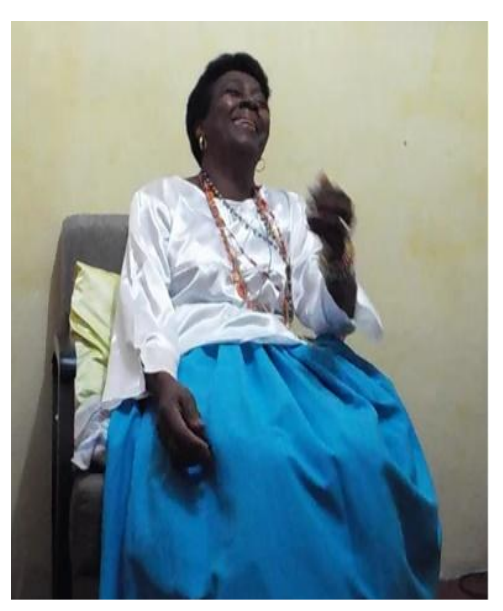

Mamãe Ossaim

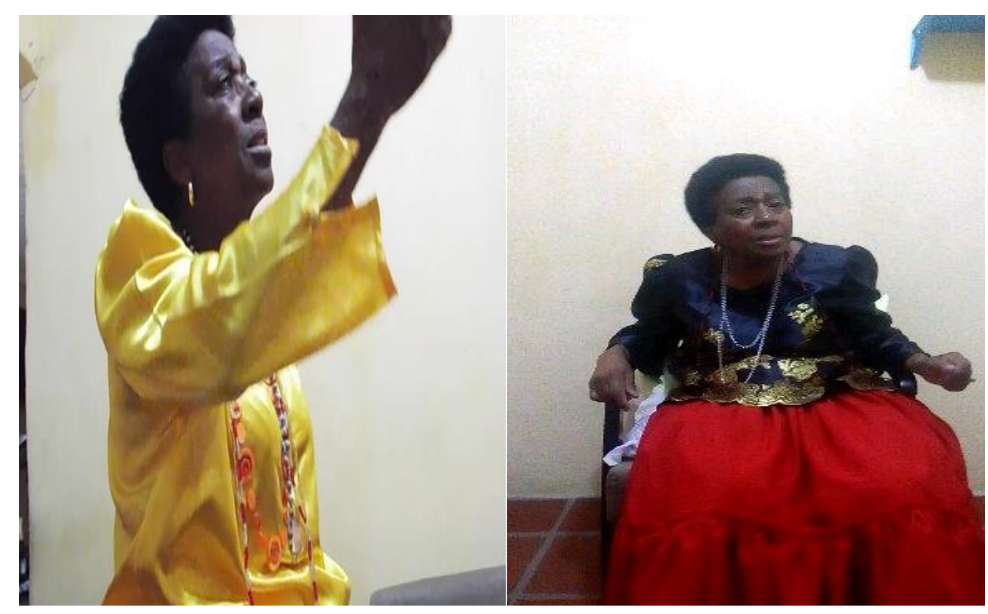

Mamãe Oxum
Exu Maria Padilha

Dona Enilda com os fardamentos representantes de entidades que trabalha.

$$
\text { Fonte: } \text { A }_{\text {autora }}{ }^{60}
$$

Finalmente, ela quis se empoderar das entidades que representa. Pelo menos algumas delas. Sei que trabalha com outras, mas pediu-me para fazer gravações com os fardamentos que enquadram cada uma de suas entidades. No entanto, independente das entidades, suas rezas e benzeduras apresentam-se sem um rito religioso ou mesmo ensinamento transcendental:

Desde a idade de oito anos, assim dizem na face da Terra, que quando eu tava na barriga da minha mãe, eu já sai pronta. Ai, eu olhava pras pessoas e sentia que as pessoas estava doente ou tava com problemas. Porque eu tinha vedência. Dai eu comecei a benzer. Pegar os gainhos de Guiné e benzê, de tesoura, assim com num

\footnotetext{
${ }^{60}$ Todas as imagens têm autorização de uso.
} 
copo com a brasa, de cobreiro, de criança pequena, de sapinho na boca, em pessoas que davam mal jeito, benze costurando num paninho. De cobreiro, de quebrante, inveja. Fazendo muitas benzeduras na terra.

- Como que a senhora aprendeu a benzedura no copo, por exemplo, quem é que ensinou as benzeduras pra senhora?

- Pegava o copo perto de mim, cheio d'água e ali eu enchia d'água, premissão do grande Pai das Alturas. E seguia benzendo com a tesoura.

- Tá, mas como que a senhora aprendeu que a benzedura era assim? Alguém lhe ensinou? - Premissão do Grande Pai das Alturas. Não teve ninguém que me ensinasse. Puxava as brasinhas, um copo com água, e ali benzia de quebrante. Quando vai todo ao fundo é porque tem quebrante. Tanto de criança quanto de gente grande. Então, aquele quebrante fica ali, vai tudo pro fundo. Por que que as pessoas melhoram? É falando na palavra de Deus, purque nós não sabemo curar, e Deus é que cura. E nos benzendo e falando em nome de Deus, ali. -A sua mãe não lhe deixou nenhuma benzedura?

-Não. E meu pai benzia muito bem. Remédio de doutor ele não acreditava, ele ia numa mata, sentia uma dor, tirava uma planta daquela mata, tomava. E bem velhinho, uma dentadura que dava gosto. E essas benzeduras de verruga, de figueira, chegava cair os pedaços da pele. -E a senhora não aprendeu nenhuma benzedura com ele também?

-Essa da berruga eu aprendi. E depois eu fui... Não tinha sessão lá onde morava. Dai começou a ter sessão. Eu dei umas voltinhas, porque me disseram que eu tinha que me desenvolver. Eu dei umas pequenas voltinhas, e graças a Deus, aquele dom que Deus me deu, tem servido pra mim e repartir com os filhos na face da terra, não é? Pra mim, é um orgulho. E tenho conversado com muita gente na terra. Então, pra mim, tem servido de uma escola. Tem muito mundo pela frente. Conversado com muitas pessoas. Visto muitas pessoas, e na face na terra acontecendo. (Dona Enilda. Gravação pessoal. Fevereiro de 2016).

\subsection{Dona Sirley: - Eu sou o cavalo dessas coisas todas}

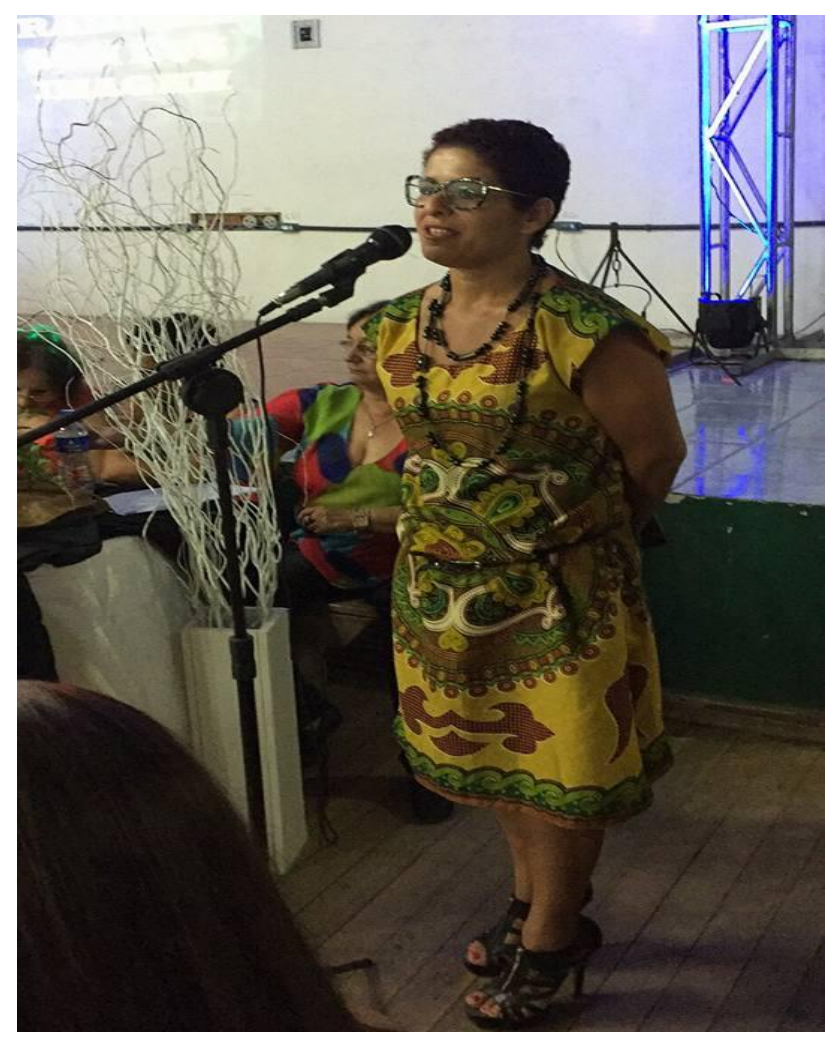

Eu com vestido feito por Dona Sirley.

Fonte: A autora 
Esta vestimenta, que uso no dia em que fui paraninfa na formatura dos meus terceiristas de 2015, foi produzida por dona Sirley. Eu quis colocar aqui, como parte de inserção do meu envolvimento com ela. Da mesma forma que dona Enilda tem a preocupação em me proteger e presentear da maneira que ela aprendeu e tem de mais valor- que são as orações e benzeduras; dona Sirley encontrou neste tecido oriundo de Guiné-Bissau - que ganhei de uma colega que lá visitou - uma forma de me agradar com seu ofício de costureira de alto padrão.

Começamos os recortes aqui em casa, medindo em detalhes cada centímetro. No entanto, sua neta adoeceu e ela teve que retornar a Pelotas. Levou consigo a costura e lá terminou. Deixou-me claro, porém, que este não era um representante da cultura africana, e que eu tinha que ter cuidado com as más representações da cultura que aqui chegam. "Os tecidos, disse ela, não têm essa característica de estampa. Estes são de origem moçambicana. E o modelo que estás pedindo, parece ser um boubou, mas não é. Ele tem mais pano em manga e não é tão duro. Então, saiba, vai ficar lindo, mas não estás representando a cultura africana."

Foi muito interessante para mim a preocupação dela em deixar claro que seria uma roupa especial e bem preparada, mas que, no entanto, eu não estaria autorizada a usá-la em caráter representativo da cultura africana. Foi por isso que tentei descaracterizar usando cinto e salto alto, "quebrando" um pouco da rigidez que o tecido apresenta e misturando a boa intenção dela em me presentear com algo que significasse tanto, culturalmente, a nós duas.

Tendo como profissão a costura, não é de se estranhar que se interesse e se preocupe tanto com os moldes e culturas que os trajes representam.

\footnotetext{
Nós, aqui no Sul, principalmente, nos negros, no Brasil inteiro. Só aquela pessoa que estudar muito, for a África ou tiver certeza da descendência dela, ela vai usar uma roupa correspondente àquele país lá na África. Senão, eu considero que nós não temos uma identidade em termos de roupa afro. -Olha, eu estou usando essa roupa afro, descendente do país tal. A não ser que isso é uma informação direta. (Dona Sirley. Gravação pessoal. Fevereiro de 2016).
}

Dona Sirley merecidamente virou Patrimônio cultural da cidade de Pelotas devido às suas ações culturais na cidade. Mas o que de fato isso significa para a cidade? E para ela? Para a UFPel, instituição a qual lhe acolheu? O antropólogo Gilberto Velho diz que "cultura é um fenômeno abrangente que inclui todas as manifestações materiais e imateriais expressas em crenças, valores, visões de mundo existentes em uma sociedade" (VELHO, 2006, p. 238). Assim sendo, qual o valor patrimonial da cultura arraigada em dona Sirley para Pelotas?

Em uma conversa, o chefe de departamento cultural da Secretaria de cultura (Secult) de Pelotas, Lúcio Xavier, explicou-me que a cidade, desde 2013, comemora o dia do patrimônio, que é sempre em agosto. Lúcio entende que dona Sirley representa a resistência e a permanência da cultura, tradição e militância negra. Mesmo que ela não se veja como uma militante política, faz a luta através de sua memória. Dona Sirley foi escolhida como patrimônio cultural, na segunda edição do Dia do Patrimônio de Pelotas, devido à herança africana que ela carrega, uma vez que este movimento "celebra a diversidade étnica e a contribuição africana e afrodescendente na construção da história de Pelotas. Assim, a Secult traz como tema do evento A Herança Cultural Africana, como algo rico, com valor afetivo vindo de antepassados estimados". (Verso do Cartão postal distribuído durante o evento).

No entanto, perguntei a dona Sirley, em data feita, sobre como é a representação que ela tem da negritude que carrega. Ela me disse que isso é um dos pontos que "os guris" cobram. Que parece que ela não se sente negra. Então, pensa-se avessa ao que esperam dela, por não dizer coisa alguma, a não ser o que se pode dizer... e, então, sempre que um outro 
quisesse dizer alguma coisa de metafisico, demonstrar-lhe que não deu sentido a certos sinais em sua proposição (CERTEAU, 2008, p. 68). Para fechar esse assunto sobre a questão da sua representação do Dia do Patrimônio, relembrei-a esta conversa e ouvi:

\footnotetext{
- Lá no inicinho a senhora tinha me dito, que os meninos lhe criticam porque parece que a senhora não é negra, que a senhora não questiona as questões da negritude...

- Não, eu questiono. É ao contrário. É que quando eu conto... não, não é que eu não questiono...é essas coisinhas que, às vezes, eu... tá, olha, é... tá ai uma coisa que, às vezes, eu não concordo. Alguém me questionou que quando eu conto a minha história, eu conto a dos brancos, porque eu vivi junto.

- Isso. Exato. O que eu escrevo da senhora é isso.

- Porque é a minha vivência. Por exemplo. Eu tenho essa pasta que é branca e essa que é preta. Essa é branca e essa é preta. Dai essa pasta branca eu não vou falar nela. Eu vou tirar ela lá pro canto, entende?

- Claro, e a senhora teve uma ligação muito grande com a família de sua madrinha, né?

- A ponto de... Uma ligação tão grande que... olha a história que tenho pra contar agora... que eu sou tia-avó do reitor da Federal (UFPel). Se fosse um parentesco, eu não sou, mas se fosse. (Dona Sirley, gravação pessoal, julho de 2016.)
}

A mãe de dona Sirley veio de Canguçu (RS) na adolescência para trabalhar como babá na casa de um grande empresário pelotense. Esse tipo de relação empregatícia era normal na época. A menina passava a morar na casa, era adotada, porém como uma funcionária. Neste ambiente, Dona Sirley cresceu e viveu. Há um agradecimento e valorização a esta família que faz com que dona Sirley não vislumbre o quanto de exploração ocorria sobre sua mãe e sobre ela própria:

(...) eu posso dizer que aprendi etiqueta com minha madrinha: porque eu ia, já, quando eu tinha uma idade maior, eu ia pra atender ao telefone. Eu aprendi muito cedo a atender ao telefone, como gente chique: " - Alô, quem fala. ... por favor..." Abrir a porta. Às vezes, tinha aniversário. Eu era chamada só pra abrir a porta para as visitas, e... era muita coisa naquela época, né? (Dona Sirley, gravação pessoal, julho de 2016).

Por isso, ela não consegue enxergar a necessidade de reivindicar espaço social à população negra, mas valoriza e respeita muito a cultura afro-brasileira, de que é mantenedora, e levanta a sua bandeira - Com agulha, linha e pano, a griô canta e conta história. $^{61}$

Dona Sirley se entende como "uma contadora de história e vivência. Uma conversadora." (Sirley, 2014). Uma conversadora que apenas narra a sua história, com as bagagens e cores que tiveram. Continua dona Sirley à entrevistadora Ana Claudia Dias: "E eu não sabia que trazia esse direito (de ser griô) devido a, desde criança, gostar de contar casos. Nunca iria imaginar que nessa caminhada, construindo informações, histórias de vida, chegaria a isso" (idem).

A questão que me fez procurar a Secult foi a ligação entre definição do que é patrimônio, e se, assim como ocorre nas obras literárias escritas, a memória (oral) de Dona Sirley é separada de sua autoria e personalidade, ou seja, inquietava-me a dúvida: é a dona Sirley ou sua memória o patrimônio valorizado?

A resposta de Xavier veio quase que imediata: o patrimônio é ela, pois sem ela não existe memória. Questionei-o então se ela não seria o meio que constrói o patrimônio. E dei como exemplo os patrimônios materiais, que são intocáveis, no entanto, as mãos que os

${ }^{61}$ Projeto contemplado com o Prêmio Movimento 2015, organizado também pela Secult. Disponível em http://www.pelotas.rs.gov.br/noticia/noticia.htm?codnoticia=40673. Acesso em 18 de julho de 2016 . 
construíram raramente são valorizadas. Retrucou-me que sim, os prédios são intocáveis devido à cultura que eles carregam. Deste modo, patrimônio é a memória que vive dentro dos prédios.

O antropólogo José Guilherme Cantor Magnani contribui a este respeito:

Os debates sobre cultura, e não apenas no interior da Antropologia, são infindáveis, o que colocaria a necessidade de, cada vez, distinguir filiações teóricas e precisar conceitos para evitar recortes com base no senso comum. Certamente, há um aspecto positivo, nessa tentativa que, se não se resolve de pronto as múltiplas questões envolvidas, de certa forma aponta para a necessidade de uma maior abrangência e busca de novos instrumentos para lidar com a questão de patrimônio. (MAGNANI, 2013, p. 9).

Magnani evidencia em seu artigo que é necessário "transcender as classificações consagradas e encarar a questão do patrimônio não apenas em sua contemporaneidade, mas também de submetê-las a pesquisas inovadoras com novas ferramentas e novos enfoques [...]" (MAGNANI, 2013, p.10).

Com a cabeça cheia de novos conceitos e quebras de conceitos sobre patrimonização, fui questionar, portanto, a dona Sirley sobre como se sentia sendo um patrimônio cultural:

\begin{abstract}
Ai... eu não sei como que eu me sinto. Orgulho eu sinto, bah, aquela guria que estudou só até a quinta série... mas vaidade não. Como é que eu vou te dizer... eu acho que até sinto orgulho, porque eu acho que, eu fui, mas... finalmente, eu como mulher, como negra, um pedaço da nossa história foi valorizado. Fui eu que fui? Não. Eu que fui, porque fui eu... mas quantas outras Sirley têm ai na cidade, que não foram chamadas para ação griô. Tem várias senhoras negras com muita história... a parte que eu sinto, é que eu ser... quer dizer assim... se ela pode, porque eu não posso... É a minha pessoa, mas... é porque eu exponho a memória de coisas que eu achei importantes na minha trajetória, comunidade. Às vezes, eu digo assim... do que eu vi, e ouvi das pessoas que por mim passaram... Até eu disse assim pra uma pessoa: sabe quando tu vai numa terreira e dizem... olha aquela ali é cavalo da Cabocla tal, a pessoa vai até ela por causa da entidade que ela recebe. É a mesma coisa que eu. Eu sou o cavalo dessas coisas todas. (Dona Sirley, gravação pessoal, julho de 2016).
\end{abstract}

Depois deste depoimento, percebi que não faz diferença quem ou o que é o patrimônio, mas, sim, o quanto de valor e importância tem a oralidade dela para ela. O quanto sua voz se torna plural e, sim, militante de uma causa negra, feminina e velha.

\title{
2 A ouvinte aprendiz
}

Sempre que a costureira dona Sirley vem me visitar tem a intenção de me passar o seu conhecimento. Fica furiosa quando eu pego a tesoura errada para fazer um corte, por exemplo, ou pelo fato de eu simplesmente não entender a forma de montagem de um (simples, que é muito simples) fuxico. Há, para ela, uma ponta de frustração por eu não atingir o ensinamento que ela se esforça para me passar. E juro, me esforço para aprender.

O mesmo ocorre com a benzedeira dona Enilda. Por ela não ter família e ninguém que a siga em sua fé, viu em meu interesse em aprender com suas histórias de vida uma oportunidade de me transformar em sua seguidora. Sabe, sei que eu tenho mediunidade e que minhas entidades estão cada vez mais próximas a mim. E eu ficaria muito orgulhosa se coubesse a mim seguir seus passos e ter um pouquinho só da força espiritual que ela carrega, porém, não me sinto apta a isso.

Este artigo encerra-se, portanto, com a mesma sensação que encerrei a tese: vazio. Estou transbordando de amor que encontrei nas escutas que me proporcionaram este estudo. 
Voltar a elas me fez novamente evidenciar o quanto eu jamais darei conta de colocar no papel a imensidão de vida que a voz carrega. Portanto, por mais que eu tenha muito o que escrever, jamais será o suficiente. Pois as histórias seguem se reinventando a cada vez que revisito estas memórias e em mim elas se recriam. Ufa! Que bom!!

\section{REFERÊNCIAS}

CERTEAU, M. A invenção do cotidiano: 1 . Artes de fazer. Tradução de Ephraim Ferreira Alves - Petrópolis, RJ: Vozes, 2008.

CHAUI, M. S. In BOSI, E. Memória e Sociedade: Lembranças de velhos. São Paulo: T.A. Queiroz Editor, 1983.

ECKERT, C.; ROCHA, A. L. C. O tempo e a cidade. Porto Alegre, Editora da UFRGS, 2006.

FERNANDES, F. A. G.. Entre histórias e tererés: o ouvir da literatura pantaneira. São Paulo: UNESP, 2002.

KLINGER, D. Literatura e ética. Rio de Janeiro: Rocco, 2014.

MAGNANI, J. G. C. A antropologia, entre patrimônio e museos. Ponto Urbe [online] 13, 2013: 1-14.

MARTINS, J. B. D. Percursos Poéticos da voz. Sala Preta, 2008: 9-17.

NETO, A. Sagrada Esperança. Lisboa: Sá da Costa, 1974.

SANT'ANNA, M. R.. O Velho no espelho: um cidadão que envelheceu. Florianópolis: ED. da UFSC, 2000.

TETTAMANY, A. L. L.; ZALLA, J.; D‘AJELLO, L. F. T. (Org.). Sobre as poéticas do dizer: pesquisas e reflexões em oralidade. São Paulo: Letras e Voz, 2010.

VELHO, G. Patrimônio, negociação e conflito. Mana 12(1), 2006: 237-248.

ZUMTHOR, P. A letra e a voz: a literatura' medieval. São Paulo: Companhia das Letras, 1993. 